\title{
Research on the Application of Wechat in College Ideological and Political Education
}

\author{
Shaofa Yang \\ Guangdong University of Science \& Technology, Dongguan, China
}

Keywords: Wechat, College, Ideological and Political Education, Strategy

\begin{abstract}
The only way to implement modern and effective ideological and political education is by the exploring the effectiveness of ideological and political education through various channels. Wechat has become a prevalent social software among the students and has profoundly impact on them, while also it creates tough opportunities and challenges for college ideological and political education. Based on the author's experience, this paper first analyses the possibility and necessity of Wechat use in college ideological and political education, and then discusses the opportunities and challenges of Wechat use in college ideological and political education, and finally proposes the temporal effectiveness improving of Wechat use in college ideological and political education.
\end{abstract}

\section{Introduction}

With the rise and the continuing popularity of information network technology which is represented by internet, contemporary undergraduate are taking a positive attitude to meet the arrival of information age. In order to enable college ideological and political education to adapt to the development of the network era and to further strengthen and improve college ideological and political education, we must constantly adapt to the changing trends and develop educational environment at the same time. As an emerging eco-medium, Wechat is favored by more and more people especially college students due to its good compatibility and rich information of transmission mode. Therefore, it has a great and practical significance to research the function of ideological and political education in Wechat.

\section{The Possibility and Necessity of Wechat Use in College Ideological and Political Education}

The possibility of Wechat use in college ideological and political education. First of all, college students are the main audience subject of new technologies and new applications. By the influence of age-level and self-experience, those college students become the main receivers and disseminators of new emerging things. The fact that college students are the primary audience of Wechat makes it possible to carry out ideological and political education through Wechat. Secondly, through network and mobile phones, college students are able to provide hardware conditions to Wechat use. As the popularity of smart phones in the student groups and the improvement of university facilities including campus wireless network, Wechat use in ideological and political education obtains hardware support from them. Through the main platform of Wechat, mobile phones, the information of browsing and interacting need the supports of smart phones and wireless network, and which is achieved in college' s information process. Thirdly, a young and professional teaching team offers talents' support to Wechat use. Based on Wechat use, either in content or in form, college ideological and political education requires innovative thinking, creativity, operation and so on, which depends on the publisher of college ideological and political education, namely the teacheing team of college ideological and political education.

The necessity of Wechat use in college ideological and political education. First, Wechat becomes an important channel for publishing and exchanging information. It passes information to students in the manner of rich diversity and a mutual combination of graphic and texture with video so that students are able to learn easily, involved in it and interact with each other. In large college audience and diversity forms, Wechat has become a key link between universities and students, it also transfer oriented and connotative content of ideological and political education. Second, 
Wechat becomes an approach to satisfy college students' emotion, individuation and social intercourse. Herein, emotion gratification and character development must be concerned and cultivated at the crucial stage of students' growth. As a result, it is one of the issues that how to infiltrate Wechat as an important social utility into ideological and political education, in which is must dealt by college ideological and political educators. It has no specified regulations of content and form in Wechat, hence it meets the needs of college students' curiosity and freedom of individual psychological development, and it attracts college students in full measure, and also produce an effect on their externalized behavior and internalized psychology .

\section{The Opportunities and Challenges of Wechat Use in College Ideological and Political Education}

The opportunities of Wechat use in college ideological and political education. First of all, expanding temporal effectiveness and pragmaticality of ideological and political education. Wechat can broaden target audience of ideological and political education. Through publishing and forwarding, a piece of item, news, or case not merely understood and discussed by students form a certain class or academy, but also received on the radius of followers. In this way, emergencies or hot current affairs education is not bound by time and place, for that reason, Wechat can convey the events, requirements and education contents to students immediately, and bring the first-hand information to students. Secondly, integrating the contents and resources of ideological and political education. Ideological and political education can be better integrated to hot current affairs, hot comments and theoretical knowledge by the channel of Wechat. From top commentators' comments of international relations, students can make clear about the situation at home and abroad what they confronted, and then ideological and political education would be implemented with the combination of modern Chinese history and international relations. From that, under the condition of Wechat, ideological and political education can gain a better integration form the content and form, and keep pace with the times, maintain its novelty and also strengthen its attraction. Third, playing the subjective initiative of ideological and political education. One of the most difficult problems of current college ideological and political education is developing students' subjective role and changing their negative attitudes. It will guide students to comment, to think and to exchange ideas through Wechat, besides, both teachers and students in a relatively equal atmosphere of a network environment, thus they can clarify a numbers of basis issues in discussions and achieve the purpose of ideological and political education from it.

The challenges of Wechat use in college ideological and political education. First, the environment of ideological and political education is more free and more complicated. College students are in a crucial period of shaping their outlook on world, on life and value, consequently, the content and the classification of information what they contact have an essential impact to their growing. Compared with the previous information of ideological and political education which only from government, universities and other major forms of official channels, at present time, information from Wechat with plentiful content and fast speed to disseminate, which challenge college ideological and political education. Second, the teaching staff construction of ideological and political education must desiderate to be improved. As a carrier, a means and a tool, Wechat' s main value of ideological and political education is reflected by presenting and disseminating information. Therefore, the organizer, publisher and interactants whom are the teachers of college ideological and political education should play a key role in Wechat use in ideological and political education. Universities and colleges should also develop all availiable channels to infiltrate ideological and political education elements into college students by thoughs and action. Third, the initiative of college ideological and political education targets needs to be further strengthened. College students are both object and subject of college ideological and political education, and pragmaticality of college ideological and political education largely depends on how much subjective initiative that students can exert. In general, Wechat is a double edged-sword as a channel of ideological and political education, subjectively speaking, it performs the function of ideological and political education and also occupies the position of it. 


\section{Improving Effectiveness Strategies of Wechat Using in College Ideological and Political Education}

Enhancing appeals and educational features of Wechat content and form. First, increasing the informative and entertaining content in Wechat so that it can be read, understood and spoke by students. The content of Wechat is the core of ideological and political education. In new period, ideological and political education should mainly focus on current affairs, history allusions, major conferences or events, further study and employment, in which students interested. To exert subtle influence on students, it also need to relate ideological and political education to daily life in a "moisten things silently" way. Second, the form of Wechat needs to coexist with picture, text, audio and video to enhance interactivity and attractiveness. Wechat is similar to a web page format, most of its pushed information are simple titles and pictures, so it determines the first expression whether the users want to further understand about this information in most cases. Through gaming activities to encourage students to pay active attention on college Wechat such as game events competitions and draws. Accordingly, information should be "packaged with" college ideological and political education. On the basis of the psychological characteristics of college students and their specific needs in the new period, to present the information in a most acceptable way can narrow the distance with students, and also promote them to learn, to interact, and to communicate with each other, thus the value of college ideological and political education would be achieved.

Enhancing the interactivity and communication of subject and object in education by the bond of Wechat. Firstly, adjusting the teaching structure of ideological and political education and boosting the quality of Wechat management. The quality and management of the teachers determine the attractiveness of Wechat. Universities should establish a team with the combination of full-time and part-time, and with different specialties, ages and levels for ideological and political education. Strengthening the faculty' s using and management of Wechat to realize the communication between teachers and students by the manner of establishing Wechat official accounts and groups; pushing and forwarding the massage related to ideological and political education and students daily life; actively carrying out the educational work such as guiding, explanation, counseling, answering and introduction; earnestly resolving the problems of students and concerning about their dynamic, from every little things. Secondly, improving students' application of Wechat and guiding their self-managing. As a network platform, Wechat shows the complicated and diverse information. College students should improve their self-discipline and moral concepts of network and the sensibly using of Wechat. As a tool, the value of Wechat is ultimately determined by the user, so that college students should learn to discriminating the valuable and correct information and accepting and forwarding positive and value-oriented massage and also need participate actively in the interaction of materials or activities.

Ensuring the adequate regulatory regimes and guarantee mechanism in organization and system. First of all, Wechat should gain significant supports from material and organization. All assumptions need certain guarantee mechanism to verify its implementation. On one hand, universities and colleges using Wechat for ideological and political education needs a necessary funding. Wechat operations in all aspects including hardware devices or software releases and maintenance requires a certain level of financial support, for which, it is necessary to start form different angles such as country, society and university, to protect Wechat use in ideological and political education in different feedback methods. At the organizational level, ideological and political education is applied to a combining education with recreation and vivid activities, and also need a set of organization to cooperate in forming a specific responsibility and collaborative planning team. With the form of working group, the ingenuity and enthusiasm of the staff in different positions can be fully motivated, thereby the organizational guarantee will be realized. Second, to establish a regulatory mechanism of government, operator, and universities working together. A good regime will guarantee the educational implementation. Universities and colleges should provide positive massages in full measure and reduce harmful information at the same time. They also need establish a reasonable monitoring system and feedback mechanism to optimize Wechat function, while encouraging students properly use Wechat. It benefits students to develop 
their healthy thoughts and emotion from Wechat, consequently, Wechat will be an effective carrier of ideological and political education.

\section{References}

[1] Quan Yongli. To Enhance the Research of College Ideological and Political Education With the Carrier of Wechat [D]. Jilin University, 2015.

[2] Wang Sen. Effects and Strategy of Wechat on College Ideological and Political Education [D]. Taiyuan University of Technology, 2015.

[3] Ji Haiju. Research on College Ideological and Political Education in New Media Age [D]. Nanjing Normal University, 2013.

[4] Hu WEi. Research on the Power of Discourse of College Ideological and Political Education in “Micro-Era” [D]. Guangxi University, 2014.

[5] Tian Zhongjin. Challenge and Countermeasure Research to College Ideological and Political Education of Wechat [D] Jilin University, 2014. 